\title{
Critical Review: Singapore: a 'NewAlexandria'of the Par East" dan "Cruel Temtation': A Case Study of a Korean Drama and its Reception in the Singaporean Community"
}

\author{
Bambang Dharwiyanto Putro \\ Prodi Antropologi FIB Unud \\ bambang_dp@unud.ac.id
}

\begin{abstract}
This paper was compiled inspired by two articles previously written by experts such as: Prof. Dr. Phil. I Ketut Ardhana, MA "Singapore: a 'NewAlexandria'of the Far East" in this book Tourism, Cultural Identity, and Globalization Singapore (2007), discusses a lot about Singapore from a historical perspective by seeing Singapore as a New Alexandaria country and the work of Kellie Chen " Cruel Temtation ': A Case Study of a Korean Drama and its Reception in the Singaporean Community "(2011). Next, a critical review will be carried out and an analysis of the contribution of Cultural Studies (its paradigm, its theoretical framework) to Singapore's development (Epistemology). Cultural studies (cultural studies) is an interdisciplinary or postdisciplinary field of inquiry that explores the production and cultivation of meaning maps as well as a discursive formation.
\end{abstract}

Keywords: paradigm, epistemology, discursive formation.

\begin{abstract}
Abstrak
Makalah ini disusun terinspirasi dari dua artikel yang sebelumnya telah ditulis oleh pakar seperti: Prof. Dr. Phil. I Ketut Ardhana, MA "Singapore: a 'NewAlexandria'of the Far East" dalam buku Tourism, Cultural Identity, and Globalization ini Singapore (2007), banyak membahas Singapore dari perspeftif sejarah dengan melihat Singapura sebagai negara Alexandaria Baru dan karya Kellie Chen " Cruel Temtation': A Case Study of a Korean Drama and its Reception in the Singaporean Community" (2011). Selanjutnya akan dilakukan critical review serta menganalisis kontribusi Kajian Budaya (paradigmanya, kerangka teorinya) terhadap pembangunan Singapura (Epistemologi). Kajian budaya (cultural studies) merupakan bidang penyelidikan interdisipliner atau postdisipliner yang mengeksplorasi produksi dan penanaman peta-peta makna sekaligus suatu formasi diskursif.
\end{abstract}

Kata Kunci: paradigma, epistemology, formasi diskursif.

\section{Pendahuluan}

Singapura merupakan negara modern yang terdiri atas beragam etnis dengan slogan promosi 'Uniquely Singapore'. Singapura tumbuh menjadi negara yang mempunyai pengaruh besar dalam perdagangan, komunikasi dan pariwisata dunia. Posisi startegis Singapura memudahkan pengembangan industri pariwisata. Dukungan lainnya adalah fasilitas-fasilitas modern bagi wisatawan, sarana transportasi yang memadai dan budaya. Komunikasi memiliki peranan penting untuk membangun jaringan pasar dunia. Dalam perdagangan, Singapura merupakan jalur transportasi yang strategis sehingga Singapura memegang peranan penting dalam perdagangan dunia, khususnya Asia Tenggara.
Perkembangan Singapura tidak hanya berada dalam keadaan saat ini saja. Di balik kesuksesan Singapura, tentu ada sejarah yang menjadi latar belakangnya. Dalam artikel Singapore: a 'New Alexandria' of the Far East, I Ketut Ardhana menilik perkembangan Singapura dimulai dari: (1) bagaimana latar belakang sejarah Singapura menjadi negara modern; (2) faktor eksternal yang mempengaruhi perkembangan Singapura pada awal abad ke-21; (3) perkembangan isu-isu yang terjadi di Singapura, seperti masalah sosial, budaya dan ekonomi.

\section{Geografis dan Sejarah Latar Belakang}

Singapura merupakan salah satu negara di Asia Tenggara yang terletak sekitar 137 km 
sebelah utara dari khatulistiwa di ujung selatan Semenanjung Malaysia dan terletak di antara Samudera Hindia dan Laut Cina Selatan. Wilayah Singapura terdiri atas pulau Singapura dan 58 pulau lainnya. Lebih dari dua pulau di wilayah Singapura tidak berpenghuni. Sepanjang $42 \mathrm{~km}$ dari barat ke timur dan $23 \mathrm{~km}$ dari utara ke selatan menjadikan Singapura menjadi negara terkecil ke-19 di dunia (Komandoko, 2010: 529).

Meskipun, kita tahu bahwa catatan awal Singapura tidak jelas. Namun, Singapura mungkin adalah rumah bagi pelabuhan kecil selama era Kekaisaran Sriwijaya. Singapura dikunjungi oleh banyak pendatang baru untuk berdagang. Menurut laporan China di 1320, pengadilan Mongol mengirim misi ke placecalled Yamen panjang untuk mendapatkan gajah. Hal ini juga mencatat bahwa pengunjung dari China, Wang Dayuan, yang datang sekitar 1330 disebut Pancur pemukiman utama di mana sudah ada orang Cina yang tinggal di tempattempat tertentu. Salah satu referensi awal ke Singapura bisa sebagai Temasek, sebuah kota laut dan berkembang pos perdagangan pada abad keempat belas. Sebuah account kontemporer Cina mengklaim bahwa Singapura adalah sebuah pulau bajak laut. The Sejarah Melayu dari catatan abad ke-16 bahwa Temasek (Singapura) adalah sebuah pos perdagangan berkembang di abad 14, dan sekitar 1390 Singapura ditaklukkan oleh Majapahit.

Seperti penjelasan sebelumnya bahwa latar belakang geografis Singapura menentukan sejarahnya. Reiger mencatat bahwa Singapura telah memainkan aturan besar karena posisi geografis dan stategis pelayanan yang baik dalam konteks perdagangan di Asia Tenggara sejak kemerdekaannya. Singapura memiliki posisi yang baik dari kapal Cina untuk mendapatkan air dan perdagangan barang yang kapal perahu dari Calcutta ke Guangzhou. Transportasi minyak dari Teluk Persia ke Jepang melalui Singapura juga dipengaruhi pembangunan di daerah. Singapura cepat menjadi sebuah kota pelabuhan utama, karena pemerintahan Inggris mempengaruhi pertumbuhan dan pentingnya negara sebagai pusat baik untuk kedua India dan perdagangan Cina. Thomas Raffles Stamport diberi izin untuk mendirikan sebuah pos perdagangan di Singapura pada tanggal 29 Januari 1819. Dia melihat potesi besar yang ada di pulau rawa yang tertutup namun berlokasi strategis.
Perkembangan ini menyebabkan, pada tahun 1832, Singapura menjadi pusat pemerintah untuk tiga wilayah. Berdasarkan data populasi Singapura, dikatakan bahwa Singapura harus mempertahankan pertumbuhan penduduknya. Ini berarti bahwa Singapura membutuhkan warga negara asing untuk datang dan menetap di negara itu. Seorang Cina memberi julukan kepada Singapura sebagai Pu-luo-chung atau Pulau di Ujung Semenanjung. Sejarah Singapura dimulai sebagai pelabuhan di bawah pemerintahan Kerajaan Sriwijaya. Berdasarkan berita Cina tahun 1320, Mongol mengirim misi yang disebut Long Yamen untuk mencari gajah. Dalam berita tersebut, Keppel Harbour menjadi benar keberadaannya. Singapura berasal dari bahasa Sanskerta yang berarti Negeri Singa (Lion City).

Perkembangan Melayu di bawah pemerintahan Inggris menjelang abad ke-20 menjadikan Singapura salah satu pelabuhan terdepan di dunia untuk ekspor timah dan karet. Perkembangan selanjutnya mengenai penanaman karet, khususnya setelah tahun 1870, Singapura menjadi pemilahan utama dan pusat ekspor karet di dunia.

Catalan penting lain yang patut diperhatikan ketika Singapura dibom oleh pesawat udara Jepang pada 8 Desember 1941. Jepang menduduki Singapura pada 15 Februari 1942 dan mengganti nama Singapura menjadi Syonan yang berarti Cahaya dari Selatan. Selama tiga tahun Jepang berkuasa di Singapura. Inggris kemudian mengambil alih kekuasaan kembali setalah tahun 1945. Ketika Pemilihan Umum pertama diselenggarakan, Lee Kuan Yew menjadi Perdana Menteri Singapura pertama. People's Action Party (PAP) membentuk persekutuan dengan kaum komunis untuk melawan Inggris. 27 Mei 1961, Perdana Menteri Melayu, Tunku Abdul Rahman mengusulkan kerja sama politik dan ekonomi antara Federasi Melayu, Singapura, Sarawak, Borneo Utara, dan Brunei. Malaysia terbentuk pada 16 September 1963 dan terdiri atas federasi Melayu, Singapura, Sarawak, dan Borneo Utara (sekarang Sabah). Namun, karena perbedaan ideologi, Singapura memutuskan keluar dari Federasi Malaysia menjadi berdaulat, demokratis dan merdeka pada 9 Agustus 1965. Singapura menjadi anggota Perserikatan Bangsa-bangsa (PBB) 21 September 1965 dan menjadi anggota Negara Persemakmuran pada 15 Oktober 1965. Singapura akhirnya menjadi negara Republik 
pada 22 Desember 1965 dengan Presiden Republik pertama Yusof bin Ishak.

Dari paparan tersebut di atas, jelas terlihat begitu kayanya daerah hinterland Singapura yang membangkitkan keinginan Inggris untuk tetap menguasai lintas perdagangan di Selat Malaka, karena Inggris paham betul bahwa dalam perdagangan laut, pelabuhan di Selat Malaka merupakan pelabuhan yang sangat strategis dalam ekonomi dan aktivitas perdagangan, disebutkan Ardhana "siapa menguasai selat malaka, maka dia yang menguasai asia tenggara/ perdagangan Asia Tenggara" (Ardhana, 2007:35).

Masalah nation dalam uraian Ardhana (2007) khusus dalam etnik dan sosialkebudayaan, Singapura bukan tanpa masalah, sebagai negara yang dibangun oleh Inggris dengan visi sebagai kota pusat dagang, pelabuhan di Selat Malaka tentu penduduknya adalah didatangkan dari luar yaitu para Pedagang Cina, India, dan asli melayu dan dari negara lainnya di Asia Tenggara. Nasionalismenya adalah bergantung pada ekonomi yang dikembangkan, sehingga dalam budaya komtemporer akan banyak mengakomodasi budaya dari luar Singapura terutama dari daerah asal migran yang tinggal di Singapura. Dapat dikatakan bahwa Singapura merupakan Negara yang multietnis, yang terdiri atas penduduk pendatang dari Cina $(76,8 \%)$, penduduk Melayu (13,9\%), , India (kebanyakan Tamil) 7,9\% dan negara lainnya 1,4\% (Chen, 2011: 5 dan Ardhana, 2007: 42). Bila ditinjau dari sudut bahasa, bahasa Melayu adalah bahasa nasional tetapi sifatnya simbolis sedangkan bahasa Inggris sebagai bahasa pengantar (lingua franca).

Penjelasan sejarah secara bagus ini, kemudian diperjelas dengan pembahasan kasus (mikro) mengenai budaya kontemporer (Budaya pop) dijelaskan oleh Kellie Chen (2011), memperkuat pandangan Adhana (2007), terutama dalam kasus kegandrungan bahkan wabah demam drama korea yang terjadi di Singapura Modern kontemporer memberikan pembuktian, betapa rapuhnya masyarakat Singapura dalam identitas budaya ke-singapuraannya. Karena Singapura berpenduduk pendatang yaitu India, melayu dan mayoritas penduduknya etnis Cina sekitar (74\%) dari seluruh jumlah penduduk sekitar 4 juta jiwa. Budaya Cina, Jepang, dan Korea memiliki ikatan emosional yang sangat intens dalam sejarahnya, dengan demikian makna yang dapat dipetik dari demam drana korea itu adalah "kerinduan masyarakat Singapura, khususnya etnis Cina terhadadap budaya dan tanah leluhurnya yang tergambar dalam dunia virtual yang dihidupkan dalam hiperrialitas (kata Piliang, 2012) bentuk drama yang ditayangkan dalam Televisi, VCD, dan media massa lainnya.

Pembahasan Kellie Chen (2011) mengenai kebudayaan penduduk kontemporer (pop), khusus dalam "cruel Temptation" dan kegilaanmasyaraka^ ${ }^{\wedge}$ Singapura terhadap drama korea, sampai membentuk kelompok penggemar drama korea, pembentukan kelompok fan, dengan rnengadakan diskusi berkala, lengkap dengan media penyebarannya, menjadikan sangat menarik pembahasan identitas kontemprer masyarakat modern Singapura. Terutama digunakan untuk mengelaborasi karya Ardhana yang berbicara masalah Singapura secara makro, terutama seperti fokus Ardhana yang telah disebutkan di atas.

Sementara itu selepas keluarnya dari Malaysia, Singapura mulai muncul sebagai kuasa perdagangan dunia. Banyak fasilitas dan kemajuan dicapai semasa pemerintahan Lee Kuan Yew. Pada tahun 1990, Lee Kuan Yew mundur dari politik dan memberi kuasa pemerintahan kepada Goh Chok Tong. Pada tahun 2004 pula, Goh Chok Tong meletakkan jabatan sebagai Perdana Menteri dan memberi jalur kepada anak Lee Kuan Yew yaitu Lee Hsien Loong untuk memerintah. http://id.wikipedia.org/wiki/Sejarah_Singapura

\section{Perkembangan Singapura Pra dan Pasca Kemerdekaan}

Kemerdekaan Singapura tidak datang dengan mendadak, sejak 1948 koloni mahkota inggris telah memilih majelis legistaltif dan dewan menteri untuk menjalankan pemerintahan dalam negeri. Sementara Singapura sudah dipisahkan Inggris dari Malaya. Tapi para pemuka politik diantaranya, Lee Kuan Yew, sadar Singapura tidak dapat berdiri sendiri atas keamanan internasional. Golongan kiri dan komunis yang masa itu masih kuat, menentang konsep penggabunga Singapura dengan Malaya, Serawak, Sabah dan Brunei dalam sebuah federasi sebagai mana diusulkan oleh Teungku Abdul Rahman. 1964 di Singapura terjadi 
keributan yang menewaskan 22 orang dan melukai 451 orang, ketegangan dan saling mengancam antara Singapura dan Kuala Lumpur memuncak yang akhirnya diputuskan untuk berpisah tanggal 9 Aagustus 1965 Singapura berdiri sendiri sebagai Negara berdaulat.

Singapura sebagai Negara dan bangsa tidak menempuh revolusi bersenjata untuk merdeka dari penjajahan tapi tidak berarti berjalan tanpa pergolakan berdarah. Ketegangan dan keresahan sosial politik tidak saja terjadi antar kelompok ideologis dan kelompok dan rasial tetapi antara pemerintah Negara bagian Singapura dan pemerintah federasi di Kuala Lumpur. Sejak itu Negara dan bangsa Singapura harus menghadapi sendiri segala tantangan masa depan dan dunia luar yang tidak penuh ketidak pastian. Tantangan tadi melahirkan sifat dinamis orang singapura yang sampai sekarang terus ditempa agar menjadi bangsa yang utuh.

Lokasi yang strategis menjadikan Singapura sebagai pintu gerbang jazirah malaka. Hal ini yang dimanfaatkan oleh pemerintah Inggris untuk mengembangkan kepentingan politik dan ekonomi kolonialnya di Asia Tenggara. Pada awal kemerdekaannya Singapura berpikir secara realistis dan pragmatis, dikarenakan kenyataan dan situasi yang dihadapi yakni wilayah yang

kecil. Singapura tidak menganut nasional ekonomi melainkan persaingan bebas yang artinya persaingan bebas antar pihak swasta. Komoditi yang kena bea masuk hanay tembakau dan produknya, minuman beralkoho dan segala produk minyak bumi. Singapura tidak mencapur adukkan permasalahan politik dengan persaingan dagang. Mulai dasawarsa 1980-an Singapura dengan sengaja mengeluarkan peraturanperaturan peningkatan upah secara umum. Singapura juga membuka pintu untuk jenis industri yang berintensif model dan berteknologi, hemat sumber daya dan berketrampilan tinggi.

Perkembangan selanjutnya dengan
program pembaharuan dimanan pelahar dimahirkan dengan ilmu alam. Sedangkan dalam bidang perguruan ditanamkan kesadaran dan kemauan untuk meningkatkan produktifitas kerja. Pengorganisasian ini berdasarkan pada rencana yang bertujuan jelas cara pelaksanaan dan pengawasan atas hasilnya. Pemerintah menentukan arah dan tujuan tetapi pelaksanaannya oleh pihak swasta.Singapura dalam menentukan pola pertahanan mengambil sikap seperti landak dalam hal ini menetapkan pada kemampuan sendiri dalam pertahanan. Angkatan senjata Singapura terdiri dari korps sukarela, merupakan inti dan professional, beserta korps cadangan yang terdiri dari wajib militer. Untuk membangun angkatan persenjataan ini, Singapura mencontoh Swiss, dimana anggota korps cadangan setelah wajib militer harus kembali kepasukan dalam waktu ternentu. Dalam bidang ketrampilan Singapura mencontoh dari Israel, satuan tempur pertama dilatih langsung oleh instruktur Israel. Adapun tujuan pola pertahanan Singapura untuk mencapai keadaan siap siaga dan berakhir secara cepat dan tepat.

Masalah utama yang selalu diperhatikan pemerintah adalah masalah ekonomi dan pertahanan keamanan. Dalam bidang Ekonomi masalah itu terjadi karena struktur perekonomian Singapura yang kuat dengan tingkat komodernan melebihi Negara Asia Tenggara lainnya dengan sendirinya

http://pendidikan4sejarah.blogspot.com/2011/04/ perkembangan-singapura-pra-dan- pasca.html

\section{Singapura: Menuju Kedaulatan Bangsa, Demokrasi, dan Merdeka.}

Perkembangan Malaya di bawah pemerintahan Inggris pada akhir abad 19 dan awal abad ke-20 membuat Singapura menjadi salah satu pelabuhan terkemuka dunia untuk ekspor timah dan karet dan menyebabkan Singapura menjadi pelabuhan utama untuk kapal plying antara Eropa dan Asia Timur. Kepentingan Inggris dan Belanda di kawasan itu tumbuh dengan perdagangan rempah-rempah. Pada tahun 1824 Singapura berada di bawah kendali penuh dari Inggris dan, meskipun mengandung hanya nelayan kecil dan vilage perdagangan. Pembuatan kereta api melalui Semenanjung Melayu ke Bangkok meningkatkan perdagangan Singapura dan bandara yang dibangun mempengaruhi lebih dari selayaknya suatu negara sebagai pusat komunikasi. Perlu dicatat bahwa imigrasi bebas berhasil masuk, menyebabkan dalam meningkatnya jumlah imigran Eropa, Cina, Melayu, India, Arab, dan Eurasia datang ke negara itu. Penting untuk dicatat bahwa pengaruh asing selalu memainkan peran utama di Singapura. Tidak ada legeslatif di Singapura, yang berarti bahwa perdebatan kebijakan yang terjadi, baik di India atau di 
London dan kebijakan yang dirancang khusus untuk India diadopsi oleh pemerintahan Inggris di Singapura. Itu membuat dipisahkan 'mahkota koloni' dari Inggris pada tahun 1946, ketika bekas koloni dari Straits Settlements dibubarkan. Kemakmuran Singapura hancur pada tanggal 8 Desember 1941 ketika Singapura dihancurkan oleh Jepang dengan pesawat. Singapura berganti nama Syonan berarti "Cahaya dari Selatan" oleh Jepang. Beberapa peristiwa yang mempengaruhi perkembangan Singapura. Singapura ditaklukkan dan diduduki oleh Jepang 1942-1945, dan diambil alih Inggris setelah Jepang menyerah.

Melalui Dewan Pembangunan Ekonomi, Pembangunan Bank of Singapore dan International Trading Company dengan masuknya inversment asing, basis industri Singapura adalah diversifikasi yang diperluas, dan dimodernisasi pada tahun 1960. Prioritas ekonomi diharapkan pengembangan Singapura berakar dalam pragmatisme negara. Untuk negara kota perkembangan, respon rasional dapat diterima adalah tindakan yang dapat berkontribusi pada ekonomi pengembangan Singapura. Sebuah referendum pada jangka merger antara Federasi Malaya, Singapura, Sarawak, Borneo Utara, dan Brunei tentang kerjasama ekonomi diadakan di Singapura. Brunei memilih keluar dan Indonesia dan Filipina menentang penggabungaa ini.

Singapura berhasil mengimplementasikan strategi impor dan kerjasama saham luar negeri. Sektor ekonomi didorong oleh bisnis asing dalam sistem federasi. Setelah kemerdekaan Singapura dan karena pemisahan dari negara Malaysia. Ini berarti bahwa Singapura harus menyediakan kebutuhan dasar dan isu-isu akomodasi dan sistem edukasi yang sangat kompleks. Karena pengalaman buruk dengan negara tetangga iru mencoba mencari keadilan sosial bagi Singapura. Kebijakan pemerintah haras melihat sikap manusia terutama di beberapa lembaga yang terkait dengan kepentingan ekonomi. Namun, demonstrasi dan pemogokan menentang usaha pemerintah dianggap menjadi solusi yang buruk bagi perekonomian rakyat.

Dengan kemerdekaan, Singapura memulai perjuangan untuk bertahan untuk hidup makmur sendiri, dan telah menciptakan rasa identitas nasional dan kesadaran di antara populasi yang berbeda dari imigran. Pada 1990-an, negara ini telah menjadi salah satu negara paling makmur di dunia, dengan ekonomi yang sangat maju pasar bebas, hubungan perdagangan intemasional yang kuat dan tertinggi per produk domestik bruto kapita di Asia di luar Jepang.

\section{Sejarah Modern Singapura}

Pada tahun 1965 Singapura menjadi negara yang independen dan bergabung dalam Persemakmuran Bangsa-Bangsa pada 9 Agustus 1965. Belakangan, Singapura di tahun 1965 secara resmi menjadi bagian dari Perserikatan Bangsa-Bangsa pada bulan September. Sejak, kemerdekaannya Singapura telah berhasil lolos dari belenggu hegemoni dan standar hidup mereka telah meningkat secara drastis. Saat ini, Singapura berada di daftar teratas bagi wisatawan yang mencari surga di bumi. Investasi langsung asing meningkat dan peningkatan minat untuk memenuhi standar industri internasional telah merubah Singapura menjadi pusat daerah industri, pos perdagangan, pendidikan, urbanitas dan modernitas. Singapura hari ini membanggakan keunggulan fasilitasnya yang mengundang banyak orang datang dari berbagai negara dan dari semua jalan-jalan kehidupan. Perencanaan Industri dijabarkan ke dalam pelaksanaan oleh Albert Winsemius, ekonom Belanda dan Singapura meperoleh keuntungan dari perencanaan sosial dan ekonomi yang rapi. Berdasarkan peringkat GDP , Singapura adalah negara ke 5 termakmur di dunia. Untuk pertama kalinya dalam sejarah dana ekonomi Singapura telah diperas beberapa miliar dari cadangan resmi dengan izin Presiden sebagai bagian dari paket ketahanan pada 5 Februari 2009 di bawah bimbingan Menteri Keuangan Singapura, Tharman Shanmugaratnam. Cadangan resmi Singapura sendiri mencapai US \$ 170,33 miliar. Menurut sebuah survei ekonomi Singapura menduduki peringkat 10 sebagai kota paling mahal untuk hidup di dunia. Ini adalah akibat dari penduduk yang dinamis dan kosmopolitan di Singapura yang hidup dalam keselarasan dan kekayaan dengan orang Cina lokal yang membentuk etnis mayoritas.

http://www.aseannewsnetwork.com/singapore/hi story-indonesian.html 


\section{Singapura Adalah Negara Alexandria Yang Baru}

Berdasarkan uraian mengenai latar belakang, perkembangan, dan kondisi Singapura saat ini, berbagai ilmuan menyebutkan bahwa Singapura adalah negara Alexandria yang baru. Alexandria diambil dan nama seorang raja yang sangat terkenal di dunia yaitu raja Alexander. la dibesarkan di Makedonia. Alexander dilahirkan pada tanggal 20 Juni 356 SM dari seorang raja yang bernama Fillipus II. Sejak umur 13 tahun ia belajar keilmuan kepada Aristoteles dan memasuki umur 16 tahun sudah menjadi panglima perang.

Setelah ayahnya meninggal, Alexander melanjutkan ekspedisi militer bersama pasukannya hingga menaklukkan wilayah hampir sepertiga dunia. Dalam kamus bebas ensiklopia Wikipedia dijelaskan, Alexander telah memperluas wilayah kekuasaan ayahnya hingga 50 kali lipat lebih besar dari wilayah kekuasaan yang diwariskan kepadanya. Meskipun Alexander hanya memerintah selama 13 tahun, dunia mengakui kebesarannya. Dalam setiap ekspedisi peperangan ia selalu menyertakan seorang ilmuwan untuk mengabadikan segala sesuatu yang ia lakukan. Diketahui dalam sejarah salah satu ilmuwan yang ikut bernama Callisthenes dari Yunani. Alexander juga sering mengganti nama wilayah yang ditaklukkan dengan namanya. Tercatat saat ini ada sekitar 13 wilayah di dunia yang bernama Alexandria termasuk diantaranya berada di kawasan Mesir.

Memasuki kota Alexandria kita akan disuguhi pemandangan seperti layaknya di negara Yunani dan Perancis. Di sana akan banyak sekali kita temukan bangunan-bangunan dengan gaya arsitektur kedua negara tersebut. Akulturasi budaya yang terjadi karena adanya perkawinan amalgamasi antara raja Alexandre dan ratu Mesir Cleopatra. Perbedaan kebudayaan yang mampu dijalin dengan baik sehingga melahirkan sebuah negara yang sejahtera merupakan kondisi yang mirip dengan negara Singapura saat ini. Singapura sangatlah plural dan multikultur. Memiliki cukup banyak etnis, agama, budaya, bahasa, tradisi/kebiasaan. Di bidang ekonomi, Negara Singapura termasuk negara industri yang sangat maju dengan posisi strategisnya di selat malaka. Secara umum senada dengan apa yang ditulis oleh Ardhana
(2007) bahwa Singapore: a "New Alexandria in the Far East".

\section{Masalah Pariwisata, Ekonomi dan Identitas Kebangsaan Singapura Dalam Ranah Globalisasi}

Singapura memiliki industri pariwisata yang berkembang baik, dengan lebih dari 8 juta pengunjung pada 2004. Sebagai kota kosmopolitan yang menonjolkan perbedaan ras dan budaya yang harmonis, banyak pengunjung mengunjungi Singapura sebagai tujuan, bukan hanya sebagai batu loncatan atau tempat transit. Singapura telah tercatat di antara wisatawan mancanegara sebagai tujuan wisata yang menarik, membuat pariwisata salah satu dari industry besar di Singapura. Perbedaan budayanya mencerminkan sejarah kolonialnya yang kaya dan etnis Melayu, Tionghoa, Arab dan India. Selama bertahun-tahun dianggap sebagai pusat bisnis di Asia Tenggara. Singapura memiliki daerah perbelanjaan yang berkembang yang terletak di distrik Orchard Road. Dipenuhi dengan beberapa pusat perbelanjaan, daerah ini juga memiliki banyak hotel, dan dianggap banyak orang sebagai pusat pariwisata Singapura.

Prof Ardana menjelaskan Singapura sebagai negara modern yang terbentuk dari berbagai tradisi budaya dan mempromosikan dirinya sebagai Singapura yang unik. Berdasarkan sejarahnya, Singapura merupakan tempat yang sangat strategis untuk kegiatan ekonomi dan perdagangan. Singapura tumbuh menjadi pusat internasional terpenting dalam hal perdagangan, komunikasi dan pariwisata. Dalam hal pariwisata, Singapura adalah salah satu negara di Asia Tenggara yang memberikan banyak peluang untuk mengembangkan industri pariwisata sebagai tempat tujuan berlibur terbesar, lengkap dengan fasilitas wiata, dan sistem transportasi yang canggih dan budaya hibrida. Dengan berada pada posisi strategis menyebabkan negara Singapura suskes dalam hal pariwisata. Ini dapat dipahami ketika Singapura mematuhi aturan main lalu lintas laut internasional.

Adapun keunikan daya tarik wisata terkenal lainnya termasuk Singapore Zoological Gardens dan Night Safari. Di sana orang dapat menjelajahi habitat Asia, Afrikadan Amerika Selatan di malam hari, tanpa penghalang yang 
nyata antara tamu dan binatang liar. Singapore Zoo telah merangkul konsep 'kebun binatang terbuka' yang mana hewan terjaga dengan pagar, terpisah dari pengunjung dengan parit yang kering atau basah yang tersembunyi, sebagai ganti kandang binatang. Juga terkenal Jurong Bird Park, di mana ada spesimen kehidupan burung yang bagus dari seluruh dunia, termasuk sekawanan ribuan flamingo. Pulau Sentosa, terletak di selatan Singapura, terdiri atas 20-30 landmarks, seperti Fort Siloso, yang dibangun sebagai benteng untuk bertahan dari Jepang selama PD II. http://id.wikipedia.org/wiki/Pariwisata_di_Singa pura

Singapura telah adil dan transparan di dalam negeri dalam menerapkan ekonomi pasar. Pemerintah berkaitan erat dengan sektor swasta. Pemerintah dan swasta bekerja untuk meningkatkan perekonomian dengan jalan yang terbuka untuk bekerja sama, tidak bertentangan satu sama lain namun bekerja sama dengan damai. Dampak dari kedua sektor publik dan swasta membuat Singapura sebagai pusat komersial dan tempat bagi kodisi sosial yang harmoni. Media sangat aktif melaporkan kejadian-kejadian di Singapura dan di seluruh dunia; media menyajikan informasi bagi warga Negara dan memastikan bahwa warga negara berhak mendapatkan informasi mengenai peristiwa yang terjadi dari hari ke hari.

Ekonomi Singapura sangat ramah bisnis dan dianggap sebagai yang terbaik sebagai pusat keuangan. Ada ribuan karyawan memberikan keunggulan hasil yang sama di perusahaanperusahaan multinasional yang membawa Singapura pada peta global. Dasar ekonomi pasar dikembangkan sangat baik dan sangat didukung oleh barang ekspor dan impor. Singapura telah dihormati oleh persatuanperusahaan dan masuk dalam daftar Empat macan Asia yang mengatur pasar di Asia bersama dengan Hong Kong, Korea Selatan dan Taiwan. Produk pabrik canggih dengan definisi tinggi adalah penopang utama ekonomi Singapura. Industri manufaktur di seluruh bidang elektronik, teknik kimia, pengilangan minyak bumi, mechanical engineering dan ilmu lainnya di negara yang mengembangkan kecanggihan tekhnologi di Singapura. Manufaktur menyumbang hampir 26\% terhadap GDP negara dan memproduksi $10 \%$ dari produk kue wafer di dunia. Samsul (2006: 21) menyatakan Singapura adalah negara nomor satu yang tingkat korupsinya paling kecil (skor 0,5) menurut PERC (Political and Economic Risk Consultancy).

Kemerdekaan Singapura membuat mereka berjuang untuk bertahan dengan hal-hal yang menjadi milik mereka.

Singapura memiliki salah satu pelabuhan tersibuk di dunia dan dihormati karena mempunyai pusat perdagangan foreign exchange (penukaran mata uang asing) terbesar keempat ketika diurutkan setelah pusat keuangan seperti London, Tokyo dan New York. Singapura juga mempekerjakan ribuan tenaga ahli dari seluruh dunia sehingga menjadi majikan global juga. Karena saat ini resesi global, Singapura juga terpengaruh sehingga GDP berkurang cukup besar. Tetapi, pemerintah bertujuan untuk merevitalisasi perekonomian Singapura dan mengatur kembali Singapura pada kemakmurannya setelah resesi. Singapura memiliki 14 perjanjian perdagangan bilateral dan multilateral di seluruh dunia dengan negaranegara seperti India, Cina, Asia, Korea, Eropa, Yordania, Jepang, Selandia Baru, Korea Selatan, Panama, Peru, Korea Selatan, Chili dan Amerika Serikat.

Untuk membuat Singapura menjadi pusat komersial dan wisatawan pemerintah telah melegalkan perjudian dan dua kasino telah dibangun di Marina dan Sentosa Selatan pada tahun 2005. Bangunan-bangunan milik negara dan komersial akan diterangi setelah diumumkan oleh pemerintah untuk membuat penampilan pulau secara estetika lebih menawan dibandingkan dengan negara-negara lain seperti Bangkok, Hong Kong, Shanghai dan Tokyo. Singapura merayakan masakannya setiap tahun dalam festival makanan Singapura. Tidak perlu diragukan bahwa jenis makanan yang ditawarkan dari suatu negara juga penting bagi wisatawan yang dapat beradaptasi dengan perubahan namun tidak sepenuhnya cita rasa mereka berubah ketika mencoba produk makanan. Singapura membanggakan berbagai masakan yang cocok dan memenuhi selera perorangan dan semua.

Terlepas dari apa yang diuraikan di atas, rakyat Singapura mengalami krisis identitas untuk dikembangkan menjadi identitas nasionalnya. Singapura mengakui bahwa mereka terdiri dari barbagai etnis, budaya, bahasa, dan tradisi serta identitas nasional umum hanyalah bagian dari perbedaan-perbedaan budaya asing 
yang ada (Ardhana hal. 49), terkait hal tersebut, identitas Singapura dan cara berpikir serta bertindak akan terus menerus berubah dan dipengaruhi oleh budaya dan faktor eksternal.

Terbukti dari kebingungan penduduk Singapura terhadap budaya yang dapat dijadikan identitas dirinya. Etnis Cina dengan emosional dan kedekatan emosional dan budayanya dengan Korea maka darama korea menjadi sangat disukai, bahkan pemuteran drama Korea di Chanel TV melalui TV kabel lokal menjadi sangat mewabah, bahkan menjadi "Cruel Temptation" di Singapura. Hal ini dapat dipahami, sebagai orang Cina di Rantau (Cina Hokkian dari Cina Selatan) sangat merindukan sastra dan budaya, serta drama yang mengangkat intibudayanya. Korea, Jepang dan Cina dalam sejarahnya merupakan bangsa yang memiliki satu rumpun budaya, yang membedakan hanyalah sejarahnya yang saling mendomonasi menjadikan peradaban negara itu menjadi saling bersaing.

Produk "Cruel Temptation" di Singapura dapat dikatakan merupakan simbol dari wakil modernitas yang dibangun sejalan dengan pembentukan kebudayaan konsumen oleh agen kapitalis. Seturut hal tersebut, Abdullah (2006) menyatakan bahwa persoalan yang menjadi penting adalah menyangkut masalah identitas nasional dan lokal di mana harus dilihat sekaligus dalam hal apa identitas lokal dapat ditemukan dalam kehidupan orang-orang kota yang menglobal, apakah itu sebagai resistensi ataupun sebagai bentuk okomodasi cultural (Abdullah, 2006: 38).

\section{Hegemoni dan Kapitalisasi Di Era Global}

Makna kebudayaan di hampir semua Negara di dunia kian lama kian menjadi "kebudayaan global". Dunia kian menjadi cosmopolitan, manusia saling mempengaruhi dalam hal perilaku. Di bagian dunia lain, tandatanda kehadiran budaya internasional pada kalangan kaum muda hamper terdapat dimanamana. Perdagangan, travel, dan televise bersamasama meletakkan dasar bagi suatu gaya hidup global. Tayangan televise dan film seakan-akan menciptakan citra yang serupa bagi kehidupan manusia di seluruh desa global (Abdul Muis, 2001 dalam, Sujarwa, 2010: 2).
Saat ini, aseannewsnetwork.com mencatat Singapura merupakan salah satu negara dalam daftar Empat Macan Asia bersama Hong Kong, Korea Selatan dan Taiwan. Seperti yang telah disebutkan Ardhana (2007), dasar ekonomi pasar Singapura adalah barang ekspor dan impor. Selain itu produk-produk pabrik dengan teknologi canggih juga menjadi penopang utama perekonomian Singapura. Faktor pendukung lainnya adalah letak Singapura yang strategis sebagai jalur perdagangan dunia.

Samsul (2006: 21) mengungkapkan Singapura adalah salah satu negara di Asia yang paling siap menghadapi era globalisasi. Pembaharuan data dari detik.com (diberitakan $3 / 5 / 2013$ ), Singapura dengan jumlah penduduk sekitar 3 juta orang dan pendapatan per kapita US\$ 48.595 per orang per tahun. Pendapatan per kapita Singapura merupakan pendapat perkapita tertinggi kedua setelah Jepang untuk wilayah Asia. Jika penulis membandingkan dengan Indonesia, rata- rata pendapatan per kapita warganya hanya US\$ 3.452 per orang per tahun. Artinya pendapatan perkapita Singapura kurang lebih 13 kali lipat dari rata-rata pendapatan per kapita Indonesia. Padahal Singapura merupakan negara yang sama sekali tidak memiliki sumber daya alam dan berbeda dengan keadaan di Indonesia yang memiliki limpahan sumber daya alam.

Singapura sangat mengandalkan industri untuk pengolahan barang-barang impor. Meskipun, tanpa sumber daya alam, tampaknya Singapura cerdik memanfaatkan bantuan Inggris dalam hal perindustrian. Bahan baku sumber daya alam seluruhnya merupakan impor dan Singapura mampu mengolahnya dengan teknologi yang mereka miliki. Bidang lainnya adalah pertukaran uang, Singapura turut menggunakan multi-currency yang memudahkan wisatawan asing bertransaksi di Singapura.

Apa yang telah ditulis/disampaikan oleh Kellie Chen (2011) adalah berusaha untuk menjelaskan bagaimana kebijakan ekonomi dan strategi media yang bekerja dengan cepat untuk menyebarkan berbagai produk budaya Korea di Asia merupakan salah satu contoh dalam ranah budaya globalisasi. Singapura adalah salah satu negara di negara asia yang terpengaruh oleh kebijakan yang dilakukan oleh media Korea yang melakukan promosi dengan biaya produksi dan distribusi yang relative murah ke negaranegara di Asia. Dalam hal ini Korea mampu 
menayangkan film melodrama di Singapura dengan harga yang lebih murah dibandingkan dengan jika ditayangkan di negara Jepang dan Taiwan. Penggunaan bahasa yang familiar sangat memberi tanggapan positip dari masyarakat Singapura sehingga mereka sangat menyukai film drama Korea. Sekalipun film Cruel Temptation ini adalah film drama yang paling controversial, namun masyarakat Singapura sangat doyan. Film ini disukai juga karena memperlihatkan perjuangan seorang wanita untuk mendapatkan hak atas kehidupannya. Cerita film yang membahas berbagai hal yang terkait dengan kehidupan di jaman ini baik itu budaya populer, budaya kontemporer, fashion, gaya hidup hingga gerakan feminism telah membuat film melodrama yang berjudul Cruel Tempation ini diterima dengan baik oleh masyarakat Singapura.

Terkait hal tersebut, Ardhana (2011) mengatakan bahwa pluralisme budaya masyarakat haruslah berada pada hubungan inter budaya antara minoritas dan mayoritas secara etnik. Disamping itu pula bahwa multikulturalisme terlahir dari adanya kesadaran akan perasaan kebersamaan dan identitas menyeluruh kehidupan bersama dan membentuk suatu perasaan bersama akan ketenteraman (Ardhana, 2011: 13-14). Lebih lanjut Kymlicka (2003) menyatakan bahwa bentuk-bentuk multikulturalisme dan berbagai pelaksanaanya di beberapa Negara belahan dunia tidaklah benarbenar sama satu sama lain. Masing-masing memiliki kekhasan, baik itu dalam definisinya maupun dalam pelaksanaannya (Kymlicka, 2003: 14-38). Kymlicka melihat, bahwa keberagaman definisi dan implementasi dari multikulturalisme itu bisa menimbulkan kebingungan dalam memahami apa arti multikulturalisme itu sendiri secara umum. Oleh karena itu ia berusaha untuk memberikan dasar teoritis bagi multikuturalisme dengan memakai pengertian yang berbeda (Kymlicka, 2003: 26). Film Cruel Temptation yang mengemukakan tentang perjuangan kaum perempuan, gaya hidup dan fashion serta persaingan di era modern ini sangat cocok dengan kehidupan multikultur masyarakat Singapura. Film seri melodrama Korea Cruel Temptation tidak saja sekedar film tetapi juga bisa dikatakan sebagai bentuk invasi iklan atas produk budaya yang dikembangkan oleh Korea untuk diterima oleh masyarakat Singapura.

\section{Pesan Etika Konfusianisme di Balik Drama Korea "Cruel Temptation"}

Keberhasilan Korea dalam menyebar jaring global drama televisinya sebagai salah satu bentuk budaya populer masa kini ke luar negeri tidak terlepas dari penerapan etika konfusianisme yang sekaligus juga merupakan bagian dari budaya dasar dari kehidupan seharihari Cina Singapura (Chen, 24). Intisari etika Konfusianisme adalah ketulusan dan keharmonisan, yang dijabarkan dalam relasi manusia: antara individu dengan orang tua, antara individu dengan saudara-saudaranya, antara individu dengan orang lain, dan antara individu dengan atasan. Konfusius menekankan pentingnya individu. Pengembangan individu merupakan fondasi dari pembangunan keluarga, masyarakat dan negara. Dalam banyak hal etika yang digulirkan Konfusius ini melampaui etikaetika budaya lokal. Etika ini mempunyai prinsip dalam berbagai aspek kehidupan. Ia mempunyai stuktur pemikiran yang relatif teratur yakni untuk kehidupan pribadi, keluarga, masyarakat dan Negara. (http://www.putra-putri indonesia.com/etika-konfusianisme.html).

Konfusianisme merupakan suatu ajaran yang berasal dari daratan China yang bersumber pada kitab-kitab klasik yang diajarkan seseorang yang bernama Kon $\mathrm{Fu}$ Tse (konfusius) beserta para penganutnya. Kon Fu Tse atau yang dengan bahasa latin menyebutnya Konfusius hidup sekitar tahun 551 SM sampai dengan 479 SM. Kon $\mathrm{Fu}$ Tse lahir di tengah-tengah kekacauan sosial dan politik. Kondisi sosial Cina pada masa itu diwarnai oleh ketidakteraturan, degradasi moral yang bermuara pada dehumanisasi. Pada masa itu, tidak ada lagi rasa saling menghargai, saling menghormati satu terhadap yang lain, antara kelompok atau negara yang satu dan kelompok atau negara yang lain terjadi ketegangan. Hal ini disebabkan karena masingmasing individu berusaha memisahkan diri dari kebersamaan demi kepentingan pribadinya. Akibatnya, mereka yang memiliki kuasa semakin berkuasa, sedangkan yang tidak mempunyai kuasa harus rela diperalat demi kepentingan penguasa. Berhadapan dengan situasi zamannya, Kon $\mathrm{Fu}$ Tse melihat bahwa persoalan utamanya adalah manusia tidak lagi dihargai sesuai dengan martabatnya. Atas dasar itu, ia ingin mengadakan reformasi masyarakat dan membentuk 
masyarakat yang hidup dalam kerukunan dan kedamaian.

Kon $\mathrm{Fu}$ Tse berkeyakinan bahwa reformasi masyarakat harus dimulai dengan mengembalikan setiap orang pada identitas aktualnya. Dengan ini, Kon Fu Tse bertekad untuk mengadakan reformasi masyarakat zamannya dengan memfokuskan perhatiannya pada manusia itu sendiri. Maka muncullah prinsip-prinsip moral dasar yang dianggap oleh Kon Fu Tse sebagai yang dapat membawa kedamaian, ketenangan dalam diri sendiri maupun bagi orang lain. Prinsip-prinsip moral dasar itu adalah Jen. Pada konsep Etik Konfusianisme, Kon $\mathrm{Fu}$ Tse menekankan perubahan diri melalui perbuatan-perbuatan yang baik, pengembangan diri guna mencapai tujuan hidup. Pemecahan atas kekacauan dan permasalahan dapat dimulai dari perubahan diri manusia itu sendiri. Konfusius Kon $\mathrm{Fu}$ Tse berkata, "Jika engkau dapat mempraktekkan kelima hal ini dengan semua orang, engkau dapat disebut Manusia Jen." Tzu Chang (muridnya) bertanya apa kelima hal itu. Konfusius berkata, "kesopanan, kemurahan, kejujuran, ketekunan dan kebajikan. Jika engkau berlaku sopan, engkau akan dihormati. Jika engkau bermurah hati, engkau akan memperoleh segala sesuatu. Jika engkau jujur, orang akan berharap padamu. Jika engkau tekun, engkau akan memperoleh hasilnya. Jika engkau bermaksud baik, engkau dapat memperkerjakan orang lain.” Kon Fu Tse menekankan konsep Jen sebagai nilai utama yang amat menentukan dalam suatu tindakan manusiawi dan pengembangan kualitas diri. Perbedaan perspektif pada saat itu, sangat sulit untuk ditemukan pengertian yang definitif dari Jen. Dari kekacauan sosial dan ekonomi yang terjadi, Jen menekankan pada pembentukan moraltias dan self-cultivasi pada setiap individu. Maka lahirlah Konsep konfusianisme apa yang disebut Etik Konfusianisme (http://dennytan90.blogspot.com/2012/01/sejarah -konfusianisme konfusianisme.html).

Perkembangan Konfusianisme melalui implementasi ajaran Konfusius telah memberikan sumbangan positif bagi pertumbuhan ekonomi yang cepat dalam rangka proses modernisasi di Singapura. Secara garis besar, ajaran Konfusius yang diimplementasikan dalam kehidupan sosial di Singapura telah menopang terjadinya pertumbuhan ekonomi Singapura yang cepat. Ajaran Konfusius yang dilihat sebagai faktor pertumbuhan ekonomi yang cepat di Singapura adalah ajaran mengenai kepatuhan dan kesetiaan, pemahaman bahwa negara adalah agen moral yang aktif dalam pembangunan masyarakat, penghormatan atas status dan hierarki, penekanan pada pengembangan diri dan pendidikan, dan perhatian terhadap harmoni sosial. Di sisi lain, penerapan etika konfusionisme menyebar dalam jaringan luas tayangan film yang masuk ke dalam tatanan masyarakat Cina Singapura sebagai mayoritas dengan alternatif penggunaan bahasa bilingual yang tersedia. Refleksinya bagi mereka bahwa konsep konfusianisme dalam etik konfusianisme adalah pengembangan sikapsikap pembenahan dan pembentukan kualitas diri. Seperti etos kerja yang giat, rajin dan serius, tunduk terhadap otoritas yang lebih tinggi, menghormati orang tua, etos kerja yang giat, rajin dan serius, selalu mencari konsensus dan keharmonisan dan menekankan pada ketertiban dan stabilitas yang pada gilirannya mencerminkan identitas tersendiri yang sangat mereka banggakan.

\section{Kontribusi Kajian Budaya Dalam Paradigma dan Kerangka Teorinya (Epistemologi)}

Apa yang dinamakan "kajian budaya" saat ini dalam bidang ilmu humaniora kurang Icbih sama dengan apa yang secara internasional dikenal sebagai cultural studies, yaitu sebuah pendekatan terhadap kebudayaan. Ada yang menyebutnya sebagai satu bentuk analisis, ada yang menyebutnya sebagai sebuah gerakan untuk membaca peta dominasi maupun resistensi. Yakni, membaca bagaimana kebudayaan menjadi arena untuk melakukan dominasi, sekaligus sebagai alat untuk memainkan negosiasi ataupun perlawanan.

Sebagai sebuah kecenderungan baru dalam pemikiran terutama di barat, cultural studies belum dapat dikatakan sebagai sebuah disiplin keilmuan yang telah mapan, melainkan sebagai sebuah ide yang tengah berkembang (ideas in progress), sebuah kecenderungan pemikiran yang masih terus mencari bentuknya. Inspirasiinspirasi awal berkembangnya ide pemikiran itu berawal dari pemikiran kebudayaan Raymond Williams yang pertama kali terlintas dalam karyanya berjudul: "Culture and Society" (1958). Baru kemudian pada tahun 1964 ide-ide 
pemikiran tersebut dilembagakan sebagai 'disiplin' yang ditandai dengan pendirian The Centre for Contemporary Cultural Studies di University of Birmingham (Inggris) dengan direktur pertamanya Richard Hoggart 1). Pada tahap awal perkembangannya, cultural studies sangat dipengaruhi oleh kecenderungan strukturalisme, baik dalam bahasa, semiotika, antropologi dan sosiologi. Perkembangan postmodemisme sebagai sebuah kecenderungan baru pemikiran mempengaruhi cultural studies pada tahap selanjutnya, yang menciptakan apa yang disebut sebagai'cultural studies postmodern'.

Sebagai sebuah ide pemikiran yang terus berkembang, cultural studies mempunyai sejarahnya yang panjang dan berlika-liku dengan berbagai pengaruh eksternal maupun internal terhadapnya. Setidaknya ada dua 'semangat jaman' (Zeitgeist) yang mempengaruhinya. yakni mainstream modernism dan posmodernisme. Pengaruh tersebut, baik implisit maupun eksplisit tampak terlintas utamanya dalam hal isu-isu yang diangkat sebagai subyect matter, kelompok pemikir yang dijadikan rujukan analisis dan juga sedikit nampak dalam hal metode yang akan dibahas sebagai-pokok uraian selanjutnya.

Metode/Teori etnografi (ethnography). Cultural studies yang menolak berbagai klaim epistemologis yang bersandar pada model pengetahuan positivistic yang lebih menekankan metode kuantitatif yang mengikuti paradigma ilmu pengetahuan alam. Dalam pandangan penganut etnograpfi cultural studies lebih mementingkan metode kualitatif dengan asumsi bahwa metode tersebut lebih mampu membentangkan segala yang "tidak eksak" yang seringkali tidak terjaring (bahkan seringkali diabaikan karena dipandang berada di luar variable yang telah ditetapkan) manakala 'sesuatu yang tidak eksak/ empiric" tersebut diangkat melalui pendekatan kuantitatif. Pada hal dalam cultural studies yang mementingkan pendekatan kualitatif memungkinkan untuk mengeksplorasi makna secara explanative (mendalam: dari yang sebatas 'etik' sampai 'emik'= thick descriptions).

Etnografi adalah salah satu metode klasik yang kemudian di dalam cultural studies dikembangkan ke arah yang lebih kualitatif. Melalui pengembangan seperti itu, etnografi cultural studies bertujuan untuk menyingkapkan dan sekaligus memahami 'makna' sebagaimana dipahami oleh sebuah komunitas atau masyarakat (etik-emik)yang dalam hal tertentu nampak berbeda dengan analogi makna semiotika atau hermeneutika (analogi filasafat tentang symbol/ tanda). Teori pembacaan (reading) selama ini sering dianggap merendahkan kemampuan masyarakat dalam memahami dirinya, yaitu bagaimana mengkaitkan sebuah fenomena kehidupan dengan situasi sosial-geografi yang kemudian membentuk "habitus" dan dan juga menjadi "ranah") yang selanjutnya dapat menentukan "praksis" (practice) setelah disinergiskan (dikalikan/ dilipat-gandakan) melalui 'modal' (sosial, budaya, ekonomi, pengetahuan, kekuasaan, dll.).

Dua tulisan dari Prof. Dr. Phil. I Ketut Ardhana, MA "Singapore: a 'NewAlexandria'of the Far East" (2007:35-51) dalam buku Tourism, Cultural Identity, and Globalization ini Singapore (2007), banyak membahas Singapore dari perspeftif sejarah dengan melihat Singapura sebagai negara Alexandaria Baru dan karya Kellie Chen " Cruel Temtation': A Case Study of a Korean Drama and its Reception in the Singaporean Community" (2011), bisa dikatakan sebagai hasil tulisan etnografi dari negara Singapura yang multikultur dari segala aspek, khususnya bidang pariwisata, ekonomi dan identitas kebangsaan Singapura dalam ranah global serta masalah budaya populer, gaya hidup dalam lingkup budaya global.

Metode semiotika (semiotics\}, Semiotika adalah ilmu yang mengkaji tentang 'tanda' sebagai bagian dari kehidupan sosial (Barker, 2004: 414). Definisi tersebut mengasumsikan bahwa tak terpisahkannya antara 'sistem tanda' dan penerapannya di dalam masyarakat. Oleh karena tanda itu selalu ditempa dalam kehidupan sosial dan budaya maka jelas keberadaan semiotika sangat sentral di dalam cultural studies. Tanda tidak berada di ruang hampa; dan oleh karenanya, ia (tanda) hanya bisa eksis bila ada 'komunitas bahasa' yang menggunakannya.

Budaya, dalam hal ini dapat dilihat sebagai 'sebuah bangunan', yang dibangun oleh kombinasi tanda-tanda, berdasarkan 'aturan' tertentu (code) untuk menghasilkan 'makna"(meaning\} (analogi Saussuran). "Tanda', dalam fenomena kebudayaan mempunyai cakupan yang sangat luas. di mana selalu unsurunsur kebudayaan itu mengandung di dalani dirinya 'makna' tertentu, maka ia adalah sebuah 
'tanda' (sign), dan dapat menjadi obyek kajian semiotika. Apakah itu pola tingkah laku seseorang, pola pergaulan, pengorganisasian ruang (komuniti), pengaturan makanan, cara berpakaian/ tata rias, pola berbelanja, hasil ekspresi seni, cara berkendaraan, permainan dan objek-objek produksi yang semuanya adalah 'produk kebudayaan'; dengan kata lain, menjadi objek semiotika dan juga cultural studies.

Sebagai sebuah cabang keilmuan, semiotika semakin memperlihatkan pengaruhnya sejak enam dekade yang lalu terutama di dalam cultural studies. Semiotika telah menjadi model atau paradigma bagi cultural studies. Sekurangkurangnya ada 4 (empat) kemampuan metode semiotika dalam cultural studies, antara lain: 1). Metode 'pembacaan' (reading), 2). 'Penciptaan'(creating), 3). Metode 'memahami kode' (decoding), dan 4). Metode 'memproduksi kode' (ecoding). Berbagai obyek kajian cultural studies, seperti sastra, media, fashion, seni film, televise, video, makanan, music, hiburan, budaya populer, budaya massa, budaya anak muda, budaya motor, subkultur dan iklan menggunakan semiotika sebagai metode utama, dengan melihatnya sebagai fenomena bahasa, tanda dan makna (Hall, 1987: 128-138).

Film serial melodrama Korea "Cruel Temptatition" dalam hal ini dapat menjadi sarana media promosi yang tepat dalam memasarkan berbagai produk fashion karena ditata dengan sangat menarik seakan tanpa cela dengan memanfaatkan para aktor serta artis dalam waktu yang panjang dalam arena episode seakan tak henti, yakni ditayangkan lebih dari seratus episode. Waktu yang sangat lama sehingga mampu menanamkan ideologi tentang gaya hidup yang ideal bagi seseorang khususnya kaum perempnan. Perjuangan kaum perempuan yang dikemas dalam film melodrama Korea Cruel Temptation tidak saja menayangkan bagaimana seorang perempuan dalam memperjuangkan hakhak emansipasinya. Di balik itu juga menciptakan kultur generasi muda yang didominasi ranah ikon fesyen, gaya musik, gaya tata rambut dan perkembangan teknologi informasi melalui televisi, yang kesemuanya menciptakan tatanan baru budaya populer kontemporer (masa kini) yang mendapat tempat tersendiri.

Metode dekontruksi (deconsiructiori), ideologi perlawanan, resistensi dan subversi yang dikembangkan dalam cultural studies memerlukan model analisis, cara berpikir maupun metode yang berkaitan dengan 'pembongkaran' terhadap berbagai struktur (bahasa, kekuasaan, institusi, dan objek sosial lainnya) yang ada, dalam rangka mengatasi berbagai bentuk ketidaksetaraan, dan ketidakadilan yang ada di dalamnya. "Dekonstruksi" (deconstructiori) yang diperkenalkan oleh Jacques Derrida adalah sebuah cara berpildr atau model analisis yang berkaitan dengan 'pembongkaran' atau 'pencairan' berbagai struktur dominan dan hegemonic itu, dalam rangka memulai sebuah permulaan baru ("memikirkan ulang") tanpa perlu melakukan 'penghancuran' (destruction) dari elemen-elemen yang telah ada. Sebagai sebuah cara berpikir, dekonstruksi sangat penting di dalam cultural studies. Melalui metode tersebut memungkinkan perhatian cultural studies masuk kepada wilayah kajian yang bersifat kontemporer seperti isyu mengenai kebebasan hasrat, kebebasan interpretasi, multisiplitas tafsiran, relativitas makna, produktivitas bahasa, dan Iain-lain. Beberapa istilah kunci yang diperkenalkan oleh Derrida di dalam dekonstruksi seperti: 'gram', 'difference' dan 'dissimination' mengandaikan sebuah ruang terbuka, yang di dalamnya segala yang telah memiliki struktur yang statis, kini harus bergerak secara dinamis dan tidak lagi dibatasi oleh relasi tetap antara signifier dan signified (Derrida, 1981: 27).

Batas-batas peninggalan inilah yang disubversi oleh metode dekonstruksi. Dekonstruksi tanda semacam ini banyak digunakan oleh berbagai kelompok praktik perlawanan budaya, seperti: subkultur, feminism, penyimpangan sexual, etnisitas, rasialisme dan Iain-lain, dengan menggelar berbagai bentuk pembongkaran struktur atau pencairan oposisi biner (binary opposition) yang membangun kebudayaan dalam rangka memproduksi tandatanda yang berbeda (meskipun tidak selalu baru). Contoh, Derrida sendiri sering aktif dalam gerakan-gerakan sosial kemanusiaan menentang politik apartheid yang dilakukannya melalui tulisan-tulisannya yang mendukung Mandela. Dalam gerakan menentang kebijakan Pemerintah Francis untuk mengurangi pelajaran filsafat di tingkat sekolah menengah ia juga tampak aktif. Begitu pula dalam gerakan-gerakan yang menentang pelanggaran hak asasi (termasuk isyu-isyu feminism) Film melodrama 
Korea "Cruel Temptation" yang juga menjelaskan tentang perjuangan seorang wanita (isyu-isyu feminism) untuk mendapatkan haknya dan dapat dihargai sangat sesuai dengan fenomena yang terjadi pada saat ini, dimana perjuangan kaum perempuan untuk bisa setara dan dihargai selayaknya kaum adam adalah hal yang patut mendapat apresiasi secara khusus. Derrida juga biasanya selalu tampil dengan nadanya yang begitu vocal (Sahal, 1994: 19).

Metode genealogi (genealogy) semakin dibutuhkan dalam cultural studies disebabkan oleh berkembangnya berbagai isu baru tentang perlawanan, resistensi, subversi dan emansipasi.

Film "Cruel Temptation" ini adalah film drama yang paling kontroversial, namun masyarakat Singapura sangat menyukainya. Film ini disukai juga karena memperlihatkan perjuangan seorang wanita untuk mendapatkan hak atas kehidupannya. Genealogi. menurut Gavin Kendall dan Gary Wickham (1999: 30) adalah suatu metode dalam 'menelanjangi diri sendiri' atau kritik ontologis diri sendiri (critical ontology of ourselves) dalam rangka membentangkan batas-batas pengetahuan terjauh yang bisa kita lewati. Genealogi mempertontonkan kepada publik berbagai aib kekuasaan yang selama ini disembunyikan di dalam berbagai wacana.

Kebenaran suatu wacana tergantung pada apa yang dikatakan, siapa yang mengatakan, kapan dan di mana ia mengatakannya. Seperti bagaimana peran perempuan dalam keluarga dan masyarakat seharusnya. Secara umum perempuan harus tunduk kepada pria dalam hidup mereka dan tujuan utama mereka harus mengurus rumah (Chen, 24). Ringkasnya, kebenaran suatu wacana tergantung pada konteksnya. Realitas sosial pun sesungguhnya juga pada dasarnya ada dalam ciptaan bahasa, dalam rekayasa permainan pengucapan yang berbeda-beda "the diversity of genres and language games" ; dan dengan begitu, tentu saja realitas bisa dimanipulasi melalui permainan bahasa tersebut. Tentang hal ini tidak bisa disangkal bahwa ada hubungan pemilihan bahasa yang digunakan dengan relasi kekuasaan yang menyelinap di baliknya (Abdurrahman, 2003: 118). Menurut Gavin Kendal dan Gary Wickham (1999: 30), geneaologi adalah suatu metode dalam 'menelanjangi diri sendiri' atau 'kritik ontologism'diri sendiri' (critical ontology of ourselves\} dalam rangka membentangkan batas- batas pengetahuan terjauh yang bisa kita lewati. Geneologi mempertontonkan pada publik berbagai aib kekuasaan yang selama ini disembunyikan di dalam berbagai wacana yang secara jelas tampak dalam tayangan serial drama korea "Cruel Temptation".

\section{Simpulan}

Artikel ini adalah melihat masalah globalisasi, yang terdiri dari tiga utama masalah. Pertama, bagaimana latar belakang historis dari Singapura untuk mengambil bentuk dalam negara modern, Kedua, jenis aspek eksternal yang memengaruhi perkembangan Singapura sampai awal abad dua puluh satu, Ketiga, apa jenis masalah dihadapi sehingga Singapura mampu untuk mengatasi berbagai masalah terutama dalam hal sosial, budaya, dan ekonomi.

Singapura telah memainkan aturan besar karena posisi geografis dan stategies pelayanan yang baik dalam konteks perdagangan di Asia Tenggara sejak kemerdekaannya. Singapura memiliki posisi yang baik dari kapal Cina untuk mendapatkan air dan perdagangan barang yang kapal perahu dari Calcutta ke Guangzhou. Singapura cepat menjadi sebuah kota pelabuhan utama, karena pemerintahan Inggris mempengamhi pertumbuhan dan pentingnya negara sebagai pusat baik untuk kedua India dan perdagangan Cina.

Aspek eksternal mempengaruhi perkembangan Singapura umumnya ditentukan oleh kerjasama politik dan ekonomi dengan negara lain yang memiliki pengaruh besar dalam dunia yang berubah. Misalnya, Bank Pembangunan Singapura dan International Trading Company dengan masuknya investasi asing berikutnya. Singapura mampu menutupi banyak masalah terutama dalam hal masalah sosial, budaya, dan ekonomi. Seperti, masalah identitas nasional. Para Singapura mengakui exstence dari berbagai etnis, agama, Languange, dan tradisi rakyat mereka. Meski telah memutuskan untuk dipisahkan dari negara Malaysia, itu mencoba mencari keadilan sosial bagi Singapura.

Identitas masyarakat multikulturalisme yang dijalankan oleh singapura disebabkan oleh 3 faktor penting. Faktor-faktor yang menyebabkan terjadinya multikulturalisme dalam suatu kesatuan identitas budaya, antara lain adalah keadaan postcolonial, masuknya 
globalisasi, perkembangan teknologi dan komunikasi. Pada suatu daerah bekas jajahan, dikarenakan adanya keinginan untuk merdeka, maka perbedaan identitas yang ada pada setiap komunitas didalamnya menjadi melebur.. Merdeka adalah satu hal yang membuat mereka dapat saling bertoleransi dan kemudian menciptakan satu identitas baru, identitas nasional. Mereka meninggalkan identitas komunitas atau daerahnya, melebur menjadi satu identitas baru, dan mau untuk menerima perbedaan yang terdapat di antara mereka.

Globalisasi juga merupakan faktor lain penyebab munculnya multikulturalisme, mengusung kekuatan ekonomi politik menuju pada satu pasar global yang besar dan multietnis. Pada bidang ekonomi, globalisasi mendorong adanya new labor migration. Dari migrasi yang terrcipta kemudian akan menambah kekayaan budaya pada suatu tempat atau negara yang dituju oleh para imigran. Melalui globalisasi ekonomi juga transaksi dalam pasar dilakukan tanpa pandang bulu dan menanggalkan aspek identitas kesukuan. Sementara pada faktor yang ketiga, perkembangan pesat yang terjadi semakin memudahkan orang untuk berpindah tempat yang berjarak ribuan mil sekalipun.

Pluralisme kultural di Asia Tenggara, khususnya Singapura, sangat mencolok; terdapat hanya beberapa wilayah lain di dunia yang memiliki pluralisme kultural seperti ini. Masyarakat plural adalah masyarakat yang terdiri dari dua atau lebih unsur-unsur atau tatanan-tatanan sosial yang hidup berdampingan, tetapi tidak bercampur dan menyatu dalam satu unit politik tunggal Singapura mampu menemukan formula kedaulatan yang menjunjung tinggi keberagaman dan menciptakan masyarakat yang mandiri sehingga tercipta negara yang makmur. Hingga saat ini, walaupu pemerintah Singapura menggalakkan kosmopolitan, namun masalah budaya dihimbau untuk tetap terjaga dan terlestarikan. Pemerintahpun membangun beberapa fasilitas, sarana, dan prasarana yang dapat digunakan warga Singapura untuk saling unjuk kebudayaan.

Pada akhirnya keberhasilan Korea dalam menyebar jaring global drama televisinya sebagai salah satu bentuk budaya populer masa kini ke luar negeri tidak terlepas dari penerapan etika konfusianisme yang sekaligus juga merupakan bagian dari budaya dasar dari kehidupan sehari-hari Cina Singapura . Intisari etika Konfusianisme adalah ketulusan dan keharmonisan, yang dijabarkan dalam relasi manusia: antara individu dengan orang tua, antara individu dengan saudara-saudaranya, antara individu dengan orang lain, dan antara individu dengan atasan. Konfusius menekankan pentingnya individu. Pengembangan individu merupakan fondasi dari pembangunan keluarga, masyarakat dan negara. Dalam banyak hal etika yang digulirkan Konfusius ini melampaui etika-etika budaya lokal.

\section{DAFTAR PUSTAKA}

Abdullah, Irwan. 2006. Konstruksi dan Reproduksi Kebudayaan. Pustaka Pelajar: Yogyakarta. Abdurrahman. 2003. Muslim, Islam Sebagai Kritik Sosial, Penerbit Erlangga Jakarta

Ardhana, I Ketut. 2007. "Singapore: A 'New Alexandria' of the East, dalam Tourism, Cultural Identity, and Globalization in Singapore. LIPI Press: Jakarta)

. 2011. "Pendahuluan Kerangka Teori dan Konsep Multikulturalisme". Dalam I Ketut Ardhana, FX Soenaryo, Sulandjari, I P utu Gede Suwitha, Ida Bagus Gde Putra ed. Masyarakat Multikultural Bali Tinjauan Sejarah, Migrasi dan Integrasi. Pustaka Larasan bekerjasama dengan Jurusan Sejarah Fakultas Sastra Universitas Udayana: Denpasar.

Barker. Chris. 2004. Cultural Studies: Teori \& Praktik(Terj.). Kreasi Wacana: Yogyakarta. . 2004. The Sage Dictionary of Cultural Studies. Sage Publications: London.

Chen, Kellie. 2011. "Cruel Temptation": A Case Study of a Korean Drama and its Reception in the Singaporean Community. Asian Languages and Cultures: Professors Deirdre De La Cruz and Youngju Ryu.

Derrida, Jacques. 1981. Position. Athlone Press.

Gavin Kendal \& Gary Wickham. 1999. Using Foucault's Methods. Sage Publication. London. Hall Stuart. 1987. Culture, Media, Language. Hutchinson, London. 
Kymlicka, Will. 2003. Kewargaan Multikultural. Pustaka LP3ES Indonesia. Komandoko, Gamal. 2010. Ensiklopedia Pelajar dan Umum. Jakarta: PT Buku

Piliang, Yasraf Amir. 2005."Cultural Studies Dan Pos Modernisme: Isyu, Teori dan Metode", Makalah, Denpasar, 12 Juli.

Samsul, Mohamad. 2006. Pasar Modal dan Manajemen Portofolio. PT Erlangga: Surabaya. Sahal, Ahmad, "Kemudian di Manakah Emansipasi? Tentang Teori Kritis, Genealogi dan Dekonstruksi”. Jurnal Kebudayaan KALAM, No. 1 thn 1994, Yayasan Kalam dan Penerbit Pustaka Grafiti, Jakarta

Sujarwa, 2010. Mitos di balik kisah-kisah sinetron dalam perspektif hegemoni dan kapitalisasi. Yogyakarta: Pustaka Pelajar

\section{Sumber Internet:}

http://id.wikipedia.org/wiki/Sejarah_Singapura

http://pendidikan4sejarah.blogspot.com/2011/04/ perkembangan-singapura-pra-danpasca.html

http://www.aseannewsnetwork.com/singapore/hi story-indonesian.html

http://id.wikipedia.org/wiki/Pariwisata_di_Singa pura

http://aseannewsnetwork.com/singapore/econom $\mathrm{y}$-indonesia.html

http://detik.com/finance/read/2013/05/03/120324 /2237204/4

http://www.putra-putri indonesia.com/etikakonfusianisme.html

http://dennytan90.blogspot.com/2012/01/sejarahkonfusianisme konfusianisme.html. 